\title{
GODŁA WSPÓLNOT KAMEDULSKICH. PRÓBA INTERPRETACJI ${ }^{1}$
}

Liczne grupy społeczne, religijne, zawodowe i rodowe, instytucje, wspólnoty osób połączonych tą samą ideą przyjmują różne znaki, których celem jest identyfikacja i wyróżnienie się we wspólnym działaniu. Wspólny znak daje także poczucie jedności. Na przestrzeni stuleci, od starożytności po czasy współczesne, różnorodne grupy ludzkie używały znaków rozpoznawczych i wyróżniających. Taką rolę spelniały znaki majstrów kamieniarskich, znaki rycerskie, herby, znaki rzemieślnicze. Taką też rolę odgrywają herby i godła wspólnot zakonnych oraz opactw i klasztorów.

\footnotetext{
${ }^{1}$ Literatura w języku polskim na temat duchowości, życia i działalności kamedułów jest nader skromna. Do najobszerniejszych opracowań o charakterze popularnym należy zaliczyć: J. K. W i e t z, P. B o h m a n n, Rys historyczny zgromadzeń zakonnych obojej plci wraz z rycerskiemi zakonami i orderami państw wydany przez..., t. 1, Warszawa 1848, s. 176-180; L. Z a r e w i c z, Erem margrabski w Szańcu. Wspomnienie historyczne, Kraków 1879 (odbitka z „Czasu”), passim; Tenże, Zakon Kamedułów, jego fundacje i dziejowe wspomnienia w Polsce i na Litwie, Kraków 1873, passim; S. P o p ł a w s k i, Kameduli w Polsce, [w:] Wielka encyklopedia ilustrowana, t. 33-34, Warszawa 1903, s. 510; A. P o p r a w a, Pustelnia OO. Kamedutów w Puszczy Kazimierskiej w województwie tódzkim. Rys historyczny od zatożenia Eremu do czasów obecnych, Bielany 1934, passim; S. Szymański, Trzysta lat Eremu Kamedulów w Bieniszewie. „Przewodnik Katolicki”. R. 55:1965, s. 326-327; T. W o j c i e c h ow s k i, Szkice historyczne XI wieku, Warszawa 1970, 39-83, 91-100; P. S c z a n i e c k i, Kameduli, [w:] Zakony benedyktyńskie w Polsce. Krótka historia, Tyniec 1981, s. 103-120; J. U r b a n, 50-lecie powrotu ojców kamedułów do pustelni „Srebrna Góra" w Bieniszewie, „Życie i Myśl”. R. 35:1987, z. 9-10, s. 143-149; Tenże, 320-lecie fundacji pustelni ojców kamedutów w Wigrach, „Życie i Myśl”. R. 35:1987, z. 11-12, s. 141-145; A. B r ü c k n e r, Encyklopedia staropolska, t. l, Waszawa 1990, kol. 515-517; M. D a n i I u k, Kameduli w Polsce, [w:] Encyklopedia katolicka, t. 7, Lublin 2000, kol. 442-443; B. Ł o z ińs k i, Leksykon zakonów w Polsce. Instytuty życia kansekrowanego i stowarzyszenia życia apostolskiego, Warszawa 2002, s. 60-61. Jeszcze skromniejsza jest literatura na temat kamedulek - zob. K. S t a r z e c, Mniszki kamedulki, [w:] Zakony benedyktyńskie..., s. 217-227; M. D a n il u k, Kamedułki, [w:] Encyklopedia katolicka, t. 7, Lublin 2000, kol. 446-447; B. Loziński, Leksykon zakonów w Polsce..., s. $230-231$.
} 
OGÓLNE UWAGI O GODEACH I HERBACH ZAKONNYCH

Termin ,herb” oznacza kompozycyjny znak rozpoznawczy. Termin ten wszedł do języka polskiego - tak twierdzi wybitny współczesny heraldyk Józef Szymański - w XVI wieku². Etymologię słowa ,herb" należy wyprowadzić od terminów „dziedzictwo" i „bron”. „Herb został wytworzony na gruncie znaków rozpoznawczych, a także własnościowym, swój rozwój w XIV wieku zawdzięcza turniejom" ${ }^{3}$. Herb wywodzi się z tradycji rycerskiej i zapewne dlatego Kościół katolicki dhugo sie przeciwstawiał ich stosowaniu. $Z$ czasem jednak przyją go i dla jego stosowania wytworzył odrębne zasady nazywane ogólnie „heraldyką kościelna"4. Wchodząca w jej skład heraldyka zakonna kieruje się własnymi zasadami, przesłankami i racjami - często niezgodnymi z ogólnie przyjętymi zasadami heraldycznymi ${ }^{5}$.

Wspomniany wcześniej prof. Józef Szymański za najstarszą cześć herbu uważa godło, które zawsze było kładzione na tarczę ${ }^{6}$. Wydaje się, że ten pogląd odnosi się do heraldyki w ogólności, także kościelnej i zakonnej.

Elementami składowymi herbu są: tarcza, godło (figura heraldyczna, mobilia herbowe), hełm, klejnot, labry, płaszcze, dewizy oraz ordery i oznaki godności. Należy także uwzględnić barwę. W heraldyce kościelnej, która nie tylko w Polsce rządziła się innymi prawami niż świecka, panują nieco inne zasady tworzenia herbów ${ }^{7}$. Jeszcze inaczej jest w heraldyce zakonnej, gdzie panują nieokreślone zasady (raczej należałoby napisać, że nie ma zasad), a samo tworzenie się znaków nazywanych symbolami, godłami lub herbami jest ciagle aktualne i żywe. Ciągle mamy do czynienia ze zjawiskiem powstawania nowych wspólnot życia konsekrowanego, które to wspólnoty przyjmują lub tworzą własne znaki. często je przekształcają lub wzbogacają dodatkowymi elementami ${ }^{8}$.

Heraldyka zakonna w wielu przypadkach sprowadza się do samego godła. Należy więc w przypadku wielu wspólnot zakonnych, w tym także w przypadku kamedułów, mówić raczej o godle niż o herbie. Często godło występuje samorodnie bez tarczy. Szerszemu omówieniu należałoby poddać zagadnienie przyczyn, sposobów i powodów powstawania znaków wyróżniających zakonne wspólnoty. Dla właściwej oceny i sprawdzenia, czy aby przyjęte godło nie jest dziełem przypadku, należy sięgnąć do pierwowzoru i przebadać genezę a także intencje pomysłodawcy znaku zakonnego".

${ }^{2}$ J. S z y m ań s k i, Herbarz średniowiecznego rycerstwa polskiego, Warszawa 1993, s. 8.

${ }^{3}$ S. G ó r z y ń s k i, J. K o c h a n ow s k i, Herby szlachty polskiej, Warszawa 1990, s. 9.

${ }^{4}$ Por. D. F. K o 1, Traktat krotki o heraldyce, to iest o herbach rodowitych..., Warszawa 1747, snlb. 9-13.

${ }^{5}$ Por. M. D a n il u k, K. K l a u z a, Podręczna encyklopedia instytutów życia konsekrowanego, Lublin 1994, s. 134.

6 J. S z y m a ń s k i , Herbarz....., s. 9.

${ }^{7}$ O heraldyce kościelnej zob.: A. D i m i e r, Araldica monastica, [w:] Dizionario degli instituti di perfezione, t. 1, Roma 1974, kol. 776-788; A. Weiss, Heraldyka kościelna. [w:] Encyklopedia katolicka, t. 6, Lublin 1993, kol. 729-736 (tamże obszerna bibliografia).

${ }^{8}$ W. K o la k, J. M a r e c k i, Leksykon godeł zakonnych, Lódź 1994, s. 13.

${ }^{9}$ Por. C. Z i el iń s k i, Sztuka sakralna, Poznań-Warszawa-Lublin 1960, s. 767. 
W heraldyce kościelnej godło zakonne traktujemy jako znak i symbol danej wspólnoty; w nim ukryta jest duchowość, cel i jej charyzmat. Rozpoznanie godła daje nam odpowiedź na pytanie o nazwę i istotę zakonu czy zgromadzenia.

\section{POCZATKI ZAKONU KAMEDUŁÓW}

Początki Zakonu Kamedułów sięgają I połowy XI wieku i związane są z postacią św. Romualda ${ }^{10}$. Urodził się około 954 roku. W wieku 20 lat wstapił do opactwa benedyktynów pod wezwaniem św. Apolinarego w Classe pod Rawenna. Tamże przyjał habit z rąk arcybiskupa Rawenny Onesto. W kilka lat później został opatem. $Z$ bliżej nieznanych przyczyn, prawdopodobnie kierował się pragnieniem prowadzenia życia doskonałego, opuścil benedyktyńską wspólnotę i rozpoczął życie samotnicze pod duchowym kierownictwem pustelnika Maryna. W $978 \mathrm{roku}$ wraz z Piotrem Orseolo opuścił Italię i udał się na półwysep Pirenejski do Katalonii. Przez pewien czas przebywał $\mathrm{w}$ benedyktyńskim opactwie pod wezwaniem św. Michała w Cuxa ${ }^{11}$ położonym w Pirenejach, kierowanym wówczas przez znanego reformatora opata Gweryna. Mieszkając w samotni w pobliżu opactwa oddał się studiowaniu pism Kasjana oraz ojców pustyni. Wielu biografów świętego twierdzi, że to właśnie pod wplywem opata Gweryna i lektury duchowej u Romualda zrodziła się koncepcja życia eremickiego, które wcielił w życie po powrocie do Italii po dziesięciu latach pobytu na terenie Hiszpanii ${ }^{12}$.

Po powrocie do Italii około 988 roku Romuald zaczął realizować swą koncepcję życia mniszego. Najczęściej przebywał w klasztorze eremie w Pereum pod Rawenną. Sława Romualda i naśladujących go uczniów sprawiła, że bardzo szybko zaczęły powstawać kolejne wspólnoty eremicko-klasztorne. Do najbardziej znanych eremów należy zaliczyć erem w Camaldoli w puszczy Casentino założony w 1025 roku. Nazwa pochodzi od nazwy miejsca podarowanego Romualdowi przez hrabiego Maldoli (Casa Maldolo albo Campo di Maldoli) w Apeninach na terenie Toskanii w pobliżu Arezzo. Od nazwy miejscowości nazwę wzięła Kongregacja Kamedułów Zakonu Świętego Benedykta. Romuald zmarł w dniu 19 czerwca 1027 roku w Val di Castro w pobliżu Ankony ${ }^{13}$.

Swoim towarzyszom i uczniom pozwalał opuszczać mury klasztorne, udawać się w głąb lasu i przebywać w nich aż do śmierci. Spotykali się siedmiokrotnie w ciagu doby na wspólna modlitwę w światyni. Zachowywali całkowite milczenie, nie spożywali potraw mięsnych, często pościli. Posiłki spożywał każdy $z$ kamedułów oddzielnie w swoim domku. Nie używali obuwia, zapuszczali długie

${ }^{10}$ Pierwszy życiorys świętego opracował P. D a mi a n i (Vita Beati Romualdi: PL 144, 953-1008).

11 Opactwo swymi początkami sięga 840 r.; w 878 r. uzyskało autonomię. Znane jako ośrodek reformy benedyktyńskiej w duchu kluniackiej odnowy życia zakonnego. Wielokrotnie niszczone (trzęsienia ziemi, wojny, rewolucja francuska) i odbudowywane.

${ }^{12}$ Por. L. Z a r e w i c z, Zakon Kamedulów..., s. 7-8; A. Butler, Il primo grande dizionario dei santi secondo il calendario, Casale Monferrato 2001, s. 602 (tamże bibliografia).

${ }^{13}$ Zob. L. Z a r e w i c z, Zakon Kamedulów..., s. 9-11; M. D a n il u k, Kameduli, kol. 439-440; A. B u $\mathrm{t}$ l e r, Il primo grande..., s. 602-603. 
brody i chodzili w białych habitach. Kolor miał oznaczać czystość i jasność intencji i życia ${ }^{14}$.

Konstytucje dla przebywających w eremie Camaldoli pustelników ułożył czwarty z kolei następca na urzędzie przełożonego św. Romualda - przeor Rudolf, późniejszy błogosławiony ${ }^{15}$. Ustawodawstwo bł. Rudolfa wprowadzało w codzienne życie mnichów modlitwę, pracę, studiowanie Biblii, także umartwiania i praktyki pokutne. Szczególnie pielęgnowano samotność jako środek do przezwyciężenia własnego ,ja" i swojej pychy; osamotnienie miało być pomoca w oderwaniu od świata. Wszystkie te praktyki miały być naturalnym środkiem do przezwyciężania pychy i egocentryzmu oraz miało pomagać do ofiarowania swego życia Bogu ${ }^{16}$. Kolejnym reformatorem kamedułów był bł. Paweł Justiniani ${ }^{17}$, o którym niżej.

Około 1085 roku w San Pietro di Luco koło Florencji przeor z Camaldoli Rudolf założył klasztor kamedułek; kolejny powstał w Pratovecchio koło Arezzo. W XII i XIII wieku powstawały tzw. klasztory podwójne, czyli takie, w których ksieni była poddana wspólnota żeńska i męska. Na ziemiach polskich pierwsze kamedułki pojawiły się w 1949 roku (Złoczew) ${ }^{18}$.

Do Polski pierwsi uczniowie św. Romualda ${ }^{19}$ - Jan $z$ Wenecji i Benedykt z Benewentu - przybyli już w pierwszych latach XI wieku. Razem z towarzyszami (tzw. Pięciu Braci Męczenników) założyli erem w pobliżu Międzyrzecza Wielkopolskiego. W listopadzie 1003 roku miał miejsce napad na klasztor. Rabusie ograbili go i wymordowali zakonników. Po dokonaniu zbrodni, prawdopodobnie w celu zatarcia śladów, podpalili kościół i uciekli. Męczenników pochował biskup poznański Unger, który też wkrótce rozpoczął starania o ich kanonizację. Papież Jan XVIII zaliczył ich w poczet świętych ${ }^{20}$.

Do grona uczniów św. Romualda należał także Bruno z Kwerfurtu, autor Vita Quinque Fratrum. W dziele tym opisał między innymi losy pierwszej fundacji w Polsce ${ }^{21}$.

${ }^{14}$ Zob. A. P a gan i, Vita di s. Romualdo abbate, fondatore dei camaldolesi, Camaldoli 1967, passim; P. S c z a n i e k i, Kameduli..., s. 106; G. Ca c c i a ma n i, Eremitismo, [w:] Dizionario enciclopedico di spiritualitá, t. 2, red. E. Ancilli, Roma 1990, s. 895-896 (tamże bogata bibliografia); M. Daniluk, Kameduli.., kol. 439-440; Święty Romuald, http://www.kameduli.pl/indexrom.php (odczyt 3 I 2006).

15 Por. Konstytucje Kongregacji Pustelników Kamedulów Góry Koronnej, KrakówBielany 1991, nr 4.

${ }^{16}$ M. D a n il u k, Kameduli..., kol. 440.

${ }^{17}$ Zob. Historia Zakonu Kamedulów, http://www.pustelnia.sandomierz.opoka.org.pl/dzieje_k.htm (odczyt 16 XII 2005); [Kameduli], http://www.republika.pl/kameduliml/Historia.htm (odczyt 16 XII 2005).

${ }_{18}$ Zob. M. D a n i l u k, Kamedulki..., kol. 446-447.

${ }^{19}$ Wedlug niektórych historyków Jan i Benedykt byli benedyktynami a nie kamedułami. Szerzej na ten temat zob. P. S c za n i e c k i, Kameduli..., s. 105.

${ }_{20}$ Por. A. B rü ckner, Encyklopedia..., kol. 515-516, ; M. D a n iluk, Kameduli w Polsce..., kol. 442; Historia Zakonu Kamedulów..., http://www.pustelnia.sandomierz.opoka.org.pl/dzieje_k.htm (odczyt 16 XII 2005).

${ }^{21}$ Zob. G. K a ro le w i c z, Bruno z Kwerfurtu, [w:] Encyklopedia katolicka, t. 2, Lub]in 1989, kol. 1110 (tamże bibliografia). 
KONGREGACJA EREMITÓW KAMEDUŁóW GÓRY KORONNEJ

Jak wspomniano wyżej jednym z reformatorów życia kamedulskiego był w XVI wieku ojciec Paweł Tomasz Justiniani, wszechstronnie wykształcony humanista - zakonnik z Camaldoli, który był założycielem Kongregacji Eremitów Kamedułów Góry Koronnej. Urodził się w dniu 16 czerwca 1476 roku w Wenecji. Kształcił się w rodzinnej miejscowości i w Padwie, gdzie odbył wszechstronne studia humanistyczne. W 1507 roku udał się na pielgrzymkę do Jerozolimy,a po powrocie do Italii, w dniu 25 grudnia 1510 roku, w eremie Camaldoli otrzymał habit oraz imię zakonne (Paweł) ${ }^{22}$. Jako przełożony eremu starał się zreformować zakon kładąc głównie nacisk na ścisłe przestrzeganie reguły pustelniczej. Zabiegał o to podczas kapituły generalnej obradującej w klasztorze Santa Maria degli Angeli we Florencji w kwietniu 1513 roku. Mimo poparcia papieża Juliusza II działalność jego w środowisku zakonnym nie była zrozumiała. Dlatego w dniu 15 września 1520 roku opuścił erem i z kilkoma towarzyszami, za zgodą papieską zamieszkał początkowo w eremie Grotte del Massaccio, a później w Grotta di Pascelupo. Założył wówczas Towarzystwo Świętego Romualda, które dało początek Kongregacji Eremitów Kamedułów Góry Koronnej ${ }^{23}$.

Bł. Paweł szczególnie akcentował znaczenie ciszy, samotność, oderwanie się od świata i zagłębienie w kontemplacje. Jego dewizą były hasło żyć sam na sam $z$ Bogiem $i$ żyć dla Boga samego. Pracując nad odnową wspólnoty napisał jedno z najważniejszych swoich pism „Regułę życia pustelniczego”. Dzieło to stało się podstawą życia dla jego zwolenników. Justiniani zmarł, prawdopodobnie z powodu zarazy panującej w Rzymie, w dniu 28 czerwca 1528 roku w klasztorze św. Sylwestra na górze Soratte ${ }^{24}$.

Następcą bł. Pawła był Justynian z Bergamo (zm. 1563), który dla nowej kongregacji założył główny erem w okolicach Perugii. Na pustelnię wybrał górę otoczoną wokól niższymi wzgórzami niczym koroną - zapewne dlatego nazwaną ją Górą Koronna, a nową kongregację Zgromadzeniem Pustelników Kamedulskich Góry Koronnej. Do tego miejsca i nazwy Kongregacji nawiązuje godło przedstawiające trzy szczyty górskie z krzyżem. Warto dodać, że do końca XIX wieku założono 37 eremów należących do tej kongregacji, głównie na Pólwyspie Apenińskim. Od 1866 roku siedzibą majora, czyli przełożonego generalnego Kongregacji, jest erem zwany Sacro Eremo Tuscolano niedaleko Frascati ${ }^{25}$.

Obecnie Kongregacja Eremitów Kamedułów Góry Koronnej, jest najliczniejsza spośród wszystkich kongregacji kamedulskich. Liczy dziewięć eremów:

${ }^{22}$ Por. P. S c zan i e c ki, Kameduli..., s. 107.

${ }^{23}$ Zob. L. Z a r e w i c z, Zakon Kamedutów..., s. 13-17; G. C a c c i a ma n i, Eremitismo..., s. 896; P. S c i andi, Giustiniani Paolo, [w:] Dizionario enciclopedico..., s. $1188-$ $-1189 ;$ M. D a n i l u k, Kameduli..., kol. 440-441.

${ }^{24}$ Por. L. Za r ew i c z, Zakon Kamedulów..., s. 13; P. S c z an i e ck i, Kameduli..., s. 107; Kongregacja Monte Corona, http://www.kameduli.pl/mcorona.php (odczyt 20 XII 2005).

${ }^{25}$ Zob. L. D e v o t i, L'Eremo Tusculano e la Villa detta dei Furii, Frascati 1981, passim; Kongregacja Monte Corona... (odczyt 15 I 2006). 
trzy we Włoszech, dwa w Polsce, po jednym w Hiszpanii, Kolumbii i Stanach Zjednoczonych i jeden w trakcie budowy w Wenezueli ${ }^{26}$.

Kameduli z Kongregacji Góry Koronnej założyli kilka klasztorów na ziemiach polskich ${ }^{27}$. Przyjmuje się, że impulsem do fundacji eremów kamedulskich stał się ruch reformy katolickiej. Eremy budowali i uposażali dobrami ziemskimi głównie królowie, a także magnaci i szlachta. W 1603 roku marszałek koronny Mikołaj Wolski sprowadził kamedułów do swoich dóbr na terenie Woli Justowskiej pod Krakowem; w pobliżu z czasem wyrosła osada nazywana zapewne od koloru zakonnego habitu Bielanami. W późniejszym okresie powstały kolejne fundacje kamedulskie na ziemiach polskich: w Rytwianach $(1624-1820)^{28}$, Bielanach pod Warszawą (1641-1902), Pożajściu (1662-1831), Bieniszewie koło Konina $(1663-1819,1937-)^{29}$, Wigrach $(1667-1800)^{30}$, w Szańcu koło Pińczowa (1722-1819) i w Milatynie Nowym (1738-1745) ${ }^{31}$.

Warto przytoczyć tekst ks. Jędrzeja Kitowicza, który charakteryzuje życie kamedułów w osiemnastowiecznej Polsce:

Te dwa zakony [kameduli i kartuzi] prowadzą życie pustelnicze, siedliska swoje mają w borach; kameduli swego klasztoru nie zowią klasztorem, tylko eremem, domki mają dla każdego osobne, a w pośrodku kościół. To zaś wszystko zabudowanie opasują murem lub drewnianym parkanem, podhug możności; chodzą w bieli, od którego koloru nazywają ich pospolicie bielanami. Gdy są w drodze, zażywają do obuwia trzewików albo botów, w eremie zaś chodzą na trepkach drewnianych, na pończochę sukienną wzutych, a do ołtarza idąc biorą na nogi pantofle, których dlatego stoi zawsze w zakrystii po kilka par. Habit ich: suknia długa, na tej szkaplerz równy z nia pasem sukiennym wąskim przypasany. Przy sukni kaptur przyszyty. Płaszcz spinający się pod szyją na guzik kościany, okrywający plecy i ramiona. Bez którego płaszcza $z$ celi, czyli chatki swojej, nie wychodzi nigdy żaden kameduła, nawet jeden do drugiego. Sypiaja w habitach, ale bez płaszcza. Mięsa w eremie nie jadaja, w domach poufałych $w$ gościnie jedza, ale bardzo rzadko i w osobności albo

${ }^{26}$ Zob. M. D a n il u k, Kameduli..., kol. 441; Kongregacja Monte Corona... (odczyt 3 I 2006).

${ }^{27}$ Kameduli, oprócz pięciu braci męczenników, pojawilisię na ziemiach polskich przed XVII wiekiem. Kamedułą był spowiednik króla Władysława Jagiełly o. Hieronim z Pragi. Zob. A. B r ü ckn e r, Kameduli..., kol. 516.

${ }^{28}$ Więcej o dawnym eremie kamedułów w Rytwianach i Stowarzyszeniu Miłośników Pustelni zob. Eremus Silvae Aureae, http://www.pustelnia.sandomierz.opoka.org.pl/ (odczyt 3 I 2006).

${ }^{29}$ Podczas II wojny światowej włađze hitlerowskie wyrzucily kamedułów z eremu; zakonnicy powrócili doń po zakończeniu działan wojennych. Szerzej o historii i życiu kamedułów w Bieniszewie zob. Miejsca kultu religijnego. Bieniszew, www.konin.lm.pl/turystyka/ (odczyt 5 II 2006).

${ }^{30}$ Zob. Wigry, http://www.suwalszczyzna.com.pl/miejsca/dane_m/wigry.htm (odczyt 1 II 2006).

${ }^{31}$ Zob. L. Z a r e w i c z, Zakon Kamedułów..., s. 22-53; Z. G l o g e r, Encyklopedia staropolska, t. 1, Warszawa 1958, s. 318-319; A. B rü ckne r, Kameduli..., kol. 516-517; P. Sczaniecki, Kameduli..., s. 108-115; Historia Zakonu Kamedutów..., http://www.pustelnia.sandomierz.opoka.org.pl/dzieje_k.htm (odczyt 10 I 2006). 
w małej kompanii. Chorzy także za pozwoleniem przełożonego i z rady lekarza używają mięsa. Stół pospolity dla całego zgromadzenia w refektarzu nie bywa u nich, tylko dwanaście razy do roku, w pewne święta. W inne dni każdy jada osobno w swojej rezydencji. Kiedy jedza w refektarzu, tedy do napoju nie zażywają szklanek, ale miseczek glinianych płaskich, wyrażając w tej manierze dawnych pustelników, którzy brali napój żółwimi skorupami; kaczki dzikie, nurkami i łysicami zwane, także bobry, wydry i żółwie jedzą za ryby, ponieważ te zwierzęta, według naturalistów, mają więcej przyrodzenia wodnego niż ziemnego; brody noszą zapuszczone, głowy całe gola, zostawując tylko waziuchna jak sznurek dokoła koronę.

Śpiewają w chórze tonem jednostajnym jak reformaci, każdą godzinę kanoniczną odprawują z osobna i po każdej wychodzą z kościoła do swoich domków, podług rozmierzonego czasu do różnych zabaw. Mszą pierwszą zaraz po prymie albo przed prymą odprawuje przeor, ostatnią konwencką po nonie hebdomadariusz, inni zaś księża wszyscy, wielu się ich znajduje w eremie, po tercji w jednej godzinie msze odprawuja, a to dlatego, żeby w chórze było ich więcej, do którego u nich należą nawet i laikowie. Mszy śpiewanej nigdy nie odprawuja, tylko czytaną (do której w dni solenne przydają turyfikacja, czyli kadzenie), chyba gość jaki śpiewa mszą podczas nabożeństwa otwartego, które bywać u nich zwykło raz albo dwa razy do roku, i na ten czas wolno białej płci wchodzić do ich kościoła. Taki odpust zowie się terminem kamedulskim ingres, na który tysiącami schodzi się do nich lud rozmaitej kondycji panów, pań i pospólstwa, a zajrzawszy tylko wielu do kościoła, cały czas trawią w puszczy na przechadzce i różnych zabawach; ponieważ zaś kameduli w wytwornym ochędóstwie trzymaja swoje kościoły, przez to po każdym ingresie umywają pawiment kościelny, zbywając tym sposobem kurzawę, błoto i pchły, naniesione do kościoła, osobliwie od kobiet, których się ten owad rad trzyma. Co dało pospólstwu przyczynę do rozumienia, iż kameduli tak się brzydzą kobietami, iż ich ślady nawet $\mathrm{z}$ kościoła swego zmywaja.

Kazania w ich nabożeństwie nie masz ani spowiedzi dla niewiast $w$ ich kościołach od ich zakonników. Jeżeli wezwani do cudzego kościola, co się trafia najwięcej do parochialnego, mają potrzebę przyjmowania spowiedzi od białej płci, to biorą na taki przypadek od swego przełożonego pozwolenie. Sami dla siebie ku pożytkowi z słowa bożego miewają egzorty mocne w kapitularzach, gdzie przełożony w sposobie zwyczajnym nauki duchownej gromi wady i błędy jakie, w swoim zgromadzeniu postrzeżone. Groby u nich są tak czyste i powietrze w nich tak wolne, że żadnego zaduchu ani wilgoci z siebie nie wydają chowaja umarlych swoich i inne osoby świeckie w katakumbach, czyli lochach murowanych. Wsunąwszy umarłego w katakumbę zasklepiają pięknie cegła i wapnem, pisząc na wierszchu, czyli facjacie, katakumby lata życia zmarłego, rok i dzień śmierci i pogrzebu. A gdy wszystkie katakumby zostaną trupami napełnione, wyjmuja najdawniejszego, przenoszą prochy jego i kości do kostnicy pospolitej, a świeżo przybylego nieboszczyka wsadzają w katakumbę wypróżniona.

Erem ich, czyli klasztor, koniecznie musi być drzewem przynajmniej na pół staja opasany, choćby dalej było pole; i nie wolno żadnego drzewa z tego okręgu klasztornego ściąć pod ekskomunika, aby tak klasztor opasany drzewem le- 
piej oznaczał pustynią. Nauk wysokich nie maja tylko teologią moralną z kazusów, nie $\mathrm{z}$ argumentów złożona. Przeor w klasztorze zawiaduje tak duchownymi, jako też doczesnymi interesami samowładnie. Do interesów doczesnych ma pomocnika, który się nazywa rządca, ale bez dołożenia się przeora niczym nie rządzi. Lubo zaś w rzeczach ważniejszych przeor obowiązany jest składać radę z starszych zakonników, przy nim jednak decyzja. A że niektórzy przeorowie nadciagnąwszy sobie władzy, zmówiwszy się z wikarym generalnym (o którego urzędzie będzie zaraz) i utrzymując się nawzajem, rządzili się absolutnie, gnębiąc swoich przeciwników, stąd urosła między nimi konfederacja jednych przeciwko drugim, czyli proces do generała i do Rzymu, który aź świecki ksiądz, delegat apostolski Wojciech Skarszewski, kanonik kamieniecki, mąż wielkiej roztropności - uspokoił, wszystkich samowładzców jako gwałcicielów ustaw zakonnych $\mathrm{z}$ urzędów pozrucawszy i za niesposobnych do piastowania ich na zawsze osądziwszy. Wikary generalny u kamedułów to znaczy, co w innych zakonach prowincjał, z tą różnica, ii ma sobie przydanych dwóch konsultorów $z$ równą swojej władza, bez których nic czynić nie może, ale dyspozycje wszystkie on tylko jeden $z$ drugim, który się wtenczas tytułuje sekretarzem, podpisuje. Wszystkich eremów kamedulskich jest w Polszcze i w Litwie siedym. Patriarchą tego zakonu jest św. Romuald ${ }^{32}$.

\section{GODŁA ZAKONU KAMEDUŁÓW I KONGREGACJI PUSTELNI- KÓW KAMEDUŁÓW GÓRY KORONNEJ - PRÓBA WYJAŚNIENIA}

Godło Zakonu Kamedułów wyobraża dwa gołębie pijące z jednego kielicha $z$ unoszącą się powyżej kometą lub gwiazdą ${ }^{33}$. Niekiedy godło to znajduje się na niebieskiej tarczy herbowej. Najczęściej tłumaczy się, że godło swymi początkami sięga czasów św. Romualda. Ma oznaczać połączenie dwóch tradycji: źycia zakonnego z pustelniczym a także tradycji Wschodu i Zachodu ${ }^{34}$. Godła tego używa zarówno męska jak i żeńska gałąź Zakonu. Obok opisanego znane sq̨ nieco zmodyfikowane wersje godła. Niekiedy nad kielichem widnieje równoramienny krzyż, którego trzy ramiona zakończone są koronami ${ }^{35}$.

Najstarszy z zachowanych wizerunków opisywanego godła pochodzi z 1183 roku i znajduje się na pieczęci przeora klasztoru kamedułów w Camaldoli. Przedstawia jedynie pijące $z$ kielicha dwa gołębie ${ }^{36}$. W XIV wieku godło było już

32 J. Kitowicz, Opis obyczajów za panowania Augusta III, Wrocław-Warszawa-Kraków 1970, s. 141.

${ }^{33} \mathrm{~W}$ heraldyce i symbolice znaczenie wymienionych cial niebieskich (gwiazdy i komety) jest zasadniczo różne - por. G. Os w al d, Lexikon der Heraldik, Leipzig 1984, s. 232; W. K o p a l i n s k i, Slownik symboli, Warszawa 1990, s. 105-108, 156.

${ }^{34}$ Swięty Romuald, http://www.kameduli.pl/indexrom.php (odczyt 22 XII 2005).

${ }^{35}$ Niekiedy uważa się, że jest to nawiązanie do nazwy Kongregacji Góry Koronnej. Por. W. K o l a k, J. M a r e c k i, Leksykon godet..., s. 134.

${ }^{36}$ Należy zauważyć, że przedstawienie gołębi pijących z kielicha, uważanie niekiedy za symbol eucharystyczny, pojawia się w ośrodkach nie związanych z kamedułami - n.p. na portalach świątyń w Perugi, Weronie oraz w Fano. Zob. G. C a c c i a ma n i, Camaldolesi, [w:] Dizionario degli istituti di perfectione, t. 1, red. G. Pelliccia, G. Rocca, Roma 1974, kol. 1724. 
w powszechnym użyciu, natomiast w trzy wieki później nad kielichem pojawia się kometa lub gwiazda. W przypadkach, gdy godło pojawiało się jako znak heraldyczny przeorów to nad tarczą umieszczano kapelusz przynależny prałatom z dwoma chwostami po obydwu stronach oraz mitra i pastoral ${ }^{37}$.

Prześledźmy znaczenie poszczególnych elementów godła.

$$
\text { gotab }
$$

Gołąb od czasów starożytnych uważany był za ptaka świętego ${ }^{38}$. Najczęściej symbolizował prostotę, miłość, skromność, niewinność oraz lagodność. Wielokrotnie występuje na kartach Pisma świętego. Wypuszczony przez Noego z arki przyniósł w dziobie gałąkę oliwną.

Ale Bóg, pamiętając o Noem, o wszystkich istotach żywych i o wszystkich zwierzętach, które $\mathrm{z}$ nim były w arce, sprawil, że powiał wiatr nad całą ziemią i wody zaczęły opadać. Zamknęły się bowiem zbiorniki Wielkiej Otchłani tak, że deszcz przestał padać z nieba. Wody ustępowały z ziemi powoli, lecz nieustannie, i po upływie stu pięćdziesięciu dni się obniżyły. Miesiąca siódmego, sieđemnastego dnia miesiąca arka osiadła na górach Ararat. Woda wciąż opadała aż do miesiąca dziesiątego. W pierwszym dniu miesiąca dziesiątego ukazały się szczyty gór. A po czterdziestu dniach Noe, otworzywszy okno arki, które przedtem uczynil, wypuścil kruka; ale ten wylatywał i zaraz wracał, dopóki nie wyschła woda na ziemi. Potem wypuścił $z$ arki gołębicę, aby się przekonać, czy ustapiły wody z powierzchni ziemi. Gołębica, nie znalazłszy miejsca, gdzie by mogła usiasść, wróciła do arki, bo jeszcze byla woda na całej powierzchni ziemi; Noe, wyciagnąwszy rękę, schwytał ja i zabrał do arki. Przeczekawszy zaś jeszcze siedem dni, znów wypuścił z arki gołębicę i ta wrócila do niego pod wieczór, niosąc $w$ dziobie świeży listek $z$ drzewa oliwnego. Poznał więc Noe, że woda na ziemi opadła. I czekał jeszcze siedem dni, po czym wypuścił znów gołębicę, ale ona już nie powróciła do niego ( $\operatorname{Rdz} 8,1-12$ ).

Powracający do arki gołąb był nie tylko znakiem opadania wód, nowej roślinności, odradzania się ziemi i nowego życia, ale także równocześnie znakiem pokoju oraz pojednania pomiędzy Bogiem i ludźmi.

Bardzo interesująca jest symbolika gołębicy (gołębia) w Księdze Pieśni nad Pieśniami oraz w Psalmach symbolika gołębia jest najwyraźniejsza.

O jak piękna jesteś, przyjaciółko moja, jak piękna, oczy twe jak gołębice! (Pnp 1, 15).

Gołąbko ma, [ukryta] w zagkębieniach skały, w szczelinach przepaści, ukaż mi swą twarz, daj mi usłyszeć swój głos!

${ }^{37}$ Zob. G. C a c c i a ma n i, Camaldolesi, [w:] Dizionario degli istituti di perfectione, t. 1, red. G. Pelliccia, G. Rocca, Roma 1974, kol. 1724; Congregatio Camaldulensis, http://www.araldicavaticana.com/zmonastici02.htm (odczyt 1 XII 2005).

${ }^{38}$ Zob. D. F o r s tn e r, Świat symboliki chrześcijańskiej, Warszawa 1990, s. 228-232;

E. D a h l e r, Święta i symbole, Warszawa 1999, s. 67-70. 
Bo słodki jest głos twój

i twarz pełna wdzięku» (Pnp 2, 14).

O jak piękna jesteś, przyjaciółko moja, jakże piękna!

Oczy twe jak gołębice

za twoją zasłoną (Pnp 4, 1a).

Ja śpię, lecz serce me czuwa:

Cicho! Oto miły mój puka!

«Otwórz mi, siostro moja, przyjaciółko moja,

gołąbko moja, ty moja nieskalana,

bo pełna rosy ma głowa

i kędziory me - kropli nocy» (Pnp 5, 2).

Oczy jego jak golębice

nad strumieniami wód (Pnp 5, 12a).

I mówię sobie: gdybym miał skrzydła jak gołąb,

to bym uleciał i spoczą -

oto bym uszedł daleko,

zamieszkał na pustyni (Ps 55, 7-8).

Gołąb wyobraża on piękno, urok, zwinność, jest również uosobieniem pokoju i pogody ducha.

Para gołębi, w Starym Testamencie składana w ofierze zwłaszcza przez ludzi ubogich, była symbolem nie tyle ubóstwa ile ofiary miłej Bogu. Taką ofiarę złożyła Święta Rodzina ${ }^{39}$. Pod postacią gołębicy ukazał się Duch Święty podczas chrztu Jezusa w Jordanie:

Wtedy przyszedł Jezus z Galilei nad Jordan do Jana, żeby przyjąć chrzest od niego. Lecz Jan powstrzymywał Go, mówiąc: «To ja potrzebuję chrztu od Ciebie, a Ty przychodzisz do mnie?» Jezus mu odpowiedział: «Pozwól teraz, bo tak godzi się nam wypełnić wszystko, co sprawiedliwe». Wtedy Mu ustapił. A gdy Jezus został ochrzczony, natychmiast wyszedł z wody. A oto otworzyły Mu się niebiosa i ujrzał Ducha Bożego zstępującego jak gołębicę i przychodzącego na Niego. A głos z nieba mówił: «Ten jest mój Syn umiłowany, w którym mam upodobanie» (Mt 3, 13-17) ${ }^{40}$.

W sztuce golębica wyobraża Ducha Świętego; jest także symbolem natchnienia pisarzy biblijnych i Ojców Kościoła. Zaznaczyć należy, że gołąb symbolizuje ludzką duszę $e^{41}$.

${ }^{39}$ Zob. Lk 2, 24.

${ }^{40}$ Por. J 1, 29-34.

${ }^{41}$ Zob. J. E. C i r 1 o t, Slownik symboli, Kraków 2000, s. 140; J. T r e s i d d e r, Symbole i ich znaczenie, Warszawa 2001, s. 68. 
Wielu znawców przedmiotu podkreśla, że do gołębicy jako Oblubienicy Chrystusa porównuje się Kościół, gdyż działa w nim i jest stale obecny Duch Święty. W tym duchu pisał św. Ambroży zaznaczając, że Kościót jest golębica z powodu laski duchowej.

Maryja, Niepokalanie Poczęta, nazwana jest jako „Czysta Gołębica”, która przyniosła ludziom zbawienie ${ }^{42}$. Często motyw gołębia z gałązką oliwną w dziobie pojawia się na sarkofagach lub nagrobkach. Symbol ten interpretuje się jako życzenie, by dusza zmarłego zaznała pokoju w zaświatach ${ }^{43}$.

\section{kielich}

Kielich jest symbolem przyjaźni i przywiązania: podczas uczty podawano go sobie $z$ rak do rak. W Piśmie świętym ma znaczenie ambiwalentne: jest symbolem gniewu Bożego i sądu oraz błogosławieństwa, radości i bliskości Boga ${ }^{44}$.

W Starym Testamencie kielich wyobraża gniew Boży:

Przebudź się, przebudź nareszcie!

Powstań, o Jerozolimo!

Ty, któraś piła z ręki Pana

puchar Jego gniewu.

Wypiłaś kielich, co sprawia zawrót głowy,

do dna go wychyliłaś (Iz 51, 17).

Tak mówi Pan Bóg:

Pić będziesz kielich twej siostry,

kielich głęboki i szeroki -

wiele on zmieści.

Upojenia i bólu jest pełen

ten kielich opuszczenia i grozy,

kielich twej siostry Samarii.

Wypijesz go aż do dna

i jeszcze w kawałki rozbijesz,

i piersi swoje rozdrapiesz,

bo Ja powiedziałem - wyrocznia Pana Boga (Ez 23, 32-34).

W podobnym tonie można odczytać słowa Księgi Apokalipsy:

A inny anioł, trzeci, przyszedł w ślad za nimi, mówiąc donośnym głosem: «Jeśli kto wielbi Bestię, i obraz jej,

i bierze sobie jej znamię na czoło lub rękę,

${ }^{42}$ Zob. M. B i e r n a c k a, Niepokalane Poczęcie, [w:] Ikonografia nowożytnej sztuki kościelnej w Polsce, red. J. Pasierb, cz. 1: Maryja Matka Chrystusa, Warszawa 1987, s. 91-92.

${ }^{43}$ Zob. E. J a st r z ę bow sk a, Daniel $i$ Tekla między lwani: antyczne korzenie sceny, [w:] studia z początków ikonografii chrześcijańskiej, red. E. Jastrzębowska, Warszawa 1998, s. 29, 45; B. F i 1 a r s k a, Archeologia chrześcijańska, Warszawa 1999, s. 86 (ryc. 60).

${ }^{44}$ Por. M. Oesterre i c h e r-Moll wo, Leksykon symboli, Warszawa 1992, s. 63. Szerzej o symbolice kielicha zob. M. L u r k e r, Slownik obrazów i symboli biblijnych, Poznań 1989, s. 192-193 (tamże bibliografia). 
ten również będzie pić wino zapalczywości Boga

przygotowane, nierozcieńczone, w kielichu Jego gniewu;

$\mathrm{i}$ będzie katowany ogniem i siarka

wobec świętych aniołów

i wobec Baranka.

A dym ich katuszy na wieki wieków się wznosi i nie mają spoczynku we dnie

i w nocy

czciciele Bestii i jej obrazu,

i ten, kto bierze znamię jej imienia» (Ap 14, 9-11).

A wielkie miasto rozpadło się na trzy części

i miasta pogan runęły.

I wspomniał Bóg na Wielki Babilon,

by mu dać kielich wina - gniewu zapalczywości swej (AP 16, 19).

Pełny kielich jest symbolem bogactwa:

Stół dla mnie zastawiasz

wobec mych przeciwników;

namaszczasz mi głowę olejkiem;

mój kielich jest przeobfity (Ps 23, 5).

Zawartość kielicha może być dobra lub zła. Przeznaczony przez Boga ludziom kielich muszą wypić wszystko:

Bo w ręku Pana jest kielich,

który się pieni winem, pełnym przypraw.

I On z niego nalewa: aż do mętów wypija

pić będą wszyscy niegodziwi na ziemi» (Ps 75, 9).

Dla chrześcijan kielich to symbol krwawej ofiary Jezusa Chrystusa ${ }^{45} \mathrm{i}$ ofiary Eucharystycznej (Mszy świętej). Najbardziej wstrząsający jest opis modlitwy Jezusa w Ogrójcu. Kielich symbolizuje wszystkie fizyczne, duchowe i moralne cierpienia Chrystusa.

Potem wyszedł i udał się, według zwyczaju, na Górę Oliwną: towarzyszyli $\mathrm{Mu}$ także uczniowie. Gdy przyszedł na miejsce, rzekł do nich: „Módlcie się, abyście nie ulegli pokusie". A sam oddalił się od nich na odległość jakby rzutu kamieniem, upadł na kolana i modlił się tymi słowami: „Ojcze, jeśli chcesz, zabierz ode Mnie ten kielich! Jednak nie moja wola, lecz Twoja niech się stanie!" W tedy ukazał Mu się anioł z nieba i umacnial Go. Pogrążony w udręce jeszcze usilniej się modlił, a Jego pot był jak gęste krople krwi, sączące się na ziemię. Gdy wstał od modlitwy i przyszedł do uczniów, zastał ich śpiących ze smutku. Rzekł do nich: „Czemu śpicie? Wstańcie i módlcie się, abyście nie ulegli pokusie" (Lk 22, 39-46).

Kielich jest także, jak wcześniej wspomniano, symbolem Mszy świętej. Podczas Ostatniej Wieczerzy Jezus podał go uczniom ze słowami:

\footnotetext{
${ }^{45}$ Por. J. 18, 11; Mt 20, 22.
} 
«Pijcie z niego wszyscy, bo to jest moja Krew Przymierza, która za wielu będzie wylana na odpuszczenie grzechów. Lecz powiadam wam: Odtąd nie będę już pił z tego owocu winnego krzewu aż do owego dnia, kiedy pić go będę $z$ wami nowy, w królestwie Ojca mojego» (Mt 26, 27b-29).

Prawdę tę powtórzył mieszkańcom Koryntu św. Paweł Apostoł:

Albowiem ja przejąłem od Pana to, co wam przekazałem, ze Pan Jezus tej nocy, której był wydany, wziął chleb, a podziękowawszy, złamał i rzekł: Bierzcie, jedzcie, to jest ciało moje za was wydane; to czyńcie na pamiątkę moją. Podobnie i kielich po wieczerzy, mówiąc: Ten kielich to nowe przymierze we krwi mojej; to czyńcie, ilekroć pić będziecie, na pamiątkę moją. Albowiem, ilekroć ten chleb jecie, a $z$ kielicha tego pijecie, śmierć Pańską zwiastujecie, aż przyjdzie" (1 Kor 11, 23-26).

W sztuce i symbolice pojawia się, związany z Męką Pańską, kielich zwany świętym Graalem. W nim to Józef z Arymatei miał, według legendarnych podań, przechowywać Krew, która po przebiciu włócznią wytrysnęła z Jezusowego bo$\mathrm{ku}^{46}$. Kielich $\mathrm{z}$ winem przypomina akt ofiary Jezusa. Jako Jego uczniowie przyjęliśmy zaproszenie do „picia” tegoż kielicha. W ten sposób mamy udział w cierpieniach Chrystusowych. Jeżeli nie będziemy pili Jego kielicha, to nie będziemy mieli udziału w Jego chwale. Kielich jest więc także emblematem wiary ${ }^{47}$.

\section{kometa}

W większości kultur kometa ma znaczenie pejoratywne. Najczęściej jest zapowiedzią klęsk, katastrof, nieurodzajów, trzęsień ziemi, zarazy, głodu lub wojny. Kometa może także oznaczać osobliwość zjawiska lub fenomen natury albo też przemijalność zjawiska i krótkotrwałą karierę. Władysław Kopaliński zwraca uwagę na jeszcze jedno znaczenie komety - mianowicie symbolizują one starców. Ogon komety przyrównywany jest do siwej brody. Kometa oznacza także człowieka przepowiadającego przyszłość ${ }^{48}$.

W sztuce chrześcijańskiej bardzo często jako kometę przedstawia się gwiazdę betlejemska, co nie jest zgodne $z$ opisem biblijnym ${ }^{49}$. Ewangelista Mateusz zdecydowanie używa słowa „gwiazda" a nie „,kometa",50.

\section{gwiazda}

Gwiazda ma wielorakie znaczenie ${ }^{51}$. Uwagę na to zwrócił najwybitniejszy z polskich znawców symboliki W. Kopaliński ${ }^{52}$. Umieszczona w godle zakonnym

${ }^{46}$ Por. R. G ill e s, Il Simbolismo nell'Arte religiosa, Roma 1993, s. 91-92; J. E. C i r I o t, Stownik symboli..., s. 148-149; J. Tr e s i d d e r, Slownik symboli, Warszawa 2001, s. 82.

${ }^{47}$ Por. J. Tr e s id de r, Stownik symboli..., s. 82.

${ }^{48}$ Por. W. Ko pal ińs k i, Stownik symboli..., s. 165; J. T re sid de r, Słownik symboli..., s. 89 .

49 Por. W. Kopaliński, Stownik symboli..., s. 165; M. Oesterreicher-

- Mollw o, Leksykon symboli..., s. 67.

${ }^{50}$ Por. Mt 2, 2-9. 
gwiazda niewątpliwie oznacza Mesjasza (Jezusa Chrystusa). Do niego odnosi się proroctwo z Księgi Liczb:

I wygłosił swoje pouczenie, mówiąc:

«Wyrocznia Balaama, syna Beora;

wyrocznia męża, który wzrok ma przenikliwy;

wyrocznia tego, który słyszy słowa Boże,

który ogląda widzenie Wszechmocnego,

a w wiedzy Najwyższego ma udział,

który pada, a oczy mu się otwieraja.

Widzę go, lecz jeszcze nie teraz,

dostrzegam go, ale nie $z$ bliska:

wschodzi Gwiazda z Jakuba,

a $z$ Izraela podnosi się berlo.

Ono to zmiażdży skronie Moabu,

a także czaszki wszystkich synów Seta (Lb 24, 15-17).

Należy też, przy interpretacji godła zakonnego kamedułów, zwrócić uwagę na inne znaczenie wizerunku gwiazdy. M. Lurker przypomina znaczenie gwiazdy jako symbolu harmonii kosmicznej oraz szczęśliwej wieczności ${ }^{53}$. Gwiazdy symbolizują także sąd Boży:

I trzeci aniol zatrabil:

i spadła $z$ nieba wielka gwiazda, płonąca jak pochodnia, a spadła na trzecią część rzek i na żródła wód.

A imię gwiazdy zowie się Piołun.

I trzecia część wód stała się piołunem, i wielu ludzi pomarło od wód, bo stały się gorzkie.

I czwarty anioł zatrabił:

i została rażona trzecia część słońca

i trzecia część księżyca i trzecia część gwiazd,

tak iż zaćmiła się trzecia ich część

i dzień nie jaśniał w trzeciej swej części,

i noc-podobnie (Ap 8, 10-12).

Wspomniany znawca symboliki biblijnej Manfred Lurker podkreśla, „że w sztuce sześcioramienna gwiazda jest często symbolem Matki Bożej. Dwa nachodzące na siebie trójkąty mają ukazywać pośrednictwo Maryi pomiędzy niebem a ziemią" ${ }^{34}$.

W wyjaśnieniu godła kamedułów przedstawiającego dwa gołębie pijace $\mathrm{z}$ jednego kielicha $\mathrm{z}$ unoszącą się powyżej kometą lub gwiazdą należy podkreślić, że wyobrażają one jedność tradycji życia wspólnotowego (cenobitycznego) i pustelniczego (eremickiego). Zarówno cenobityzm jak i eremici naśladowali Jezusa

${ }^{51}$ Zob. D. For s t ne r, Swiat symboliki..., s. 101-104.

${ }^{52}$ Por. W. K o pa l ińsk i, Stownik symboli..., s. 105-108; zob. E. D a h le r, Święta i symbole..., s. 71-75; J. E. Cir lot, Stownik symboli..., s. 153-154; J. T r e sid de r, Symbole $i$ ich znaczenie..., s. 98.

${ }^{53}$ Por. M. Lurke r, Stownik obrazów..., s. 64-65.

${ }^{54}$ M. L u rk e r, Slownik obrazów..., s. 65. 
Chrystusa, który był dla nich zarówno jedynym wzorem jak i celem. Jeśli przyjmiemy, ze gołębie symbolizują ludzie dusze to z wyobrażenia godła kamedułów można wyprowadzić myśl, iż dusze ludzkie mogą karmić się jedynie tym co najświętsze (kielich w tym przypadku symbolizuje Eucharystię). Kometa może symbolizować krótkie życie ludzi i złudną ziemską karierę albo też - co jest raczej mało prawdopodobne - eremitę w sędziwym wieku. Gwiazda - to Jezus Chrystus, który oświeca drogę mnichom i wskazuje właściwy cel życia.

Św. Romuald był przede wszystkim synem św. Benedykta i pragnął oddanie Bogu realizować przez życie zakonne. Rozumiał je jednak w specyficzny sposób. Inspiracja był dla niego monastycyzm starożytny reprezentowany przez egipski anachoretyzm i palestyńskie laury oraz współczesne mu ruchy, $\mathrm{m}$. in. aktywny na przełomie X i XI wieku ruch pielgrzymujacych (itineranti) ${ }^{55}$.

Należy zwrócić uwagę na gwiazdę jako uosobienie Maryi. Konstytucje Kongregacji Pustelników Kamedułów Góry Koronnej podkreślają

że Najświętsza Dziewica Maryja, Matka Boga i nasza, jest znakomitym przykładem życia kontemplacyjnego, dlatego niech nasi pustelnicy czczą Ją z prawdziwą miłością i ze specjalnym nabożeństwem, także przez odmawianie RóŻańca świętego ${ }^{56}$.

Kult maryjny w eremach kamedułów był zawsze żywy. Prawodawstwo zakonne przepisywało w dni poświęcone Najświętszej Maryi Pannie odmawiać antyfony i modlitwy ku jej czci ${ }^{57}$. Większość świątyń zakonnych było dedykowanych Matce Bożej, mnisi nosili przy habitach koronki lub różańce.

Składające się z przedstawionych i opisanych wyżej elementów godło kamedułów jest równocześnie ukazaniem ich duchowości, wskazań pozostawionych przez św. Romualda i współczesnego prawodawstwa Zakonu. Zakonne Konstytucje [podkreślaja, że] instytucja pustelnicza, jaką jest

Kongregacja Kamedułów Góry Koronnej, lącząc w sobie elementy istotne dla cenobityzmu, tj. regułę, władzę, życie wspólne oraz elementy anachoreckie, jak odosobnienie, milczenie, pilne przestrzeganie przebywania w celi, przedstawia harmonijne zespolenie obu tych rodzajów życia ${ }^{58}$.

Uzupełnieniem godła jest dewiza: Ego vobis, vos mihi (Ja należę do was, wy należycie do mnie) ${ }^{59}$. Przynależność do Jezusa Chrystusa łączy zakonników, buduje ich wspólnotę i pozwala wspólnie dźwigać trudy życia zakonnego.

${ }^{55}$ Por. Regula św. Benedykta i Konstytucye Zgromadzenia Kamedulów-Pustelników Góry Koronnej przejrzane i potwierdzone przez Ojca św. Klemensa IX, Kraków 1912, I; Informacje na temat sensu życia monastycznego $i$ jego roli $w$ Kościele, http://www.eremosangiorgio.it/nuova_pagina_2.htm (odczyt 28 XII 2005).

${ }^{56}$ Konstytucje Kongregacji..., nr 98.

${ }^{57}$ Por. Regula św. Benedykta i Konstytucye..., XI, 4.

${ }^{58}$ Konstytucje Kongregacji..., nr 10.

${ }^{59}$ Por. Ez 36, 28. 


\section{Św. Romuald pragnął}

połączyć charyzmatyczną wolność człowieka Bożego, „oddanego całkowicie Panu w samotności", z kościelnym zakorzenieniem pustelnika, który jest związany Reguła, posłuszeństwem i niekiedy, jak w przypadku Camaldoli, łącząc małą wspólnotę pustelniczą z klasztorem ${ }^{60}$.

Godło Kongregacji Góry Koronnej przedstawia trzy pagórki lub górskie szczyty. Ze środkowego, najwyższego, wyrasta krzyż okolony koroną ${ }^{61}$. Niekiedy obok krzyża umieszczane są inicjały łacińskiej nazwy Kongregacji „Monte Corona" ${ }^{2}$.

Godło powyższe używane bywa jako znak rozpoznawczy klasztorów należących do Kongregacji oraz, okolone nazwą jako pieczęć. Godło pojawiło się już w 1525 roku. Początkowo przedstawiało trzy wzgórza i krzyż; znacznie później pojawiła się korona - jako nawiązanie do nazwy wzgórz ${ }^{63}$.

\section{góry}

Góra jest symbolem stałości, mistyki, medytacji i samotności, miejscem, z którego blisko do nieba a także mądrości i rozeznawania drogi życiowej. Tym samym góra jest uznawana jako droga do nieba i do Boga. To właśnie na szczytach gór powstają liczne pustelnie, eremy i klasztory, gdyż pobytu tam nikt nie zakłóca. Góra jest także atrybutem pokoju i wolności ${ }^{64}$.

Góra bardzo często występuje w tekstach Pisma świętego, zarówno w Starym jak i w Nowym Testamencie ${ }^{65}$. Jahwe przebywał na górze Synaj (Horeb) i na jej szczycie zawarł z Mojżeszem przymierze:

Pan rzekł do Mojżesza: „Wstạp do Mnie na górę i pozostań tam, a dam ci tablice kamienne, Prawo i przykazania, które napisałem, aby ich pouczyć". Wstał więc Mojżesz i Jozue, jego pomocnik, i wstapił Mojżesz na górę Boża. Powiedział zaś tak do starszyzny: «Pozostańcie tu, aż wrócimy do was. Oto macie Aarona i Chura. Kto miałby jakaśs sprawę do załatwienia, może się zwrócić do nich». Gdy zaś Mojżesz wstąpil na górę, obłok ją zakrył. Chwała Pana spoczęła na górze Synaj, i okrywał ją obłok przez sześć dni. W siódmym dniu [Pan] przywołał Mojżesza z pośrodka obłoku. A wygląd chwały Pana w oczach

${ }^{60}$ Informacje na temat sensu życia... (odczyt 28 XII 2005).

${ }^{61}$ Godło Kongregacji Góry Koronnej przypomina godło benededyktynów „Monte Vergine", barnabitów, oliwietan, sylwestrynów oraz nieistniejącego już Zakonu Kleryków Regularnych Teatynów. Zob. Por. W. K o l a k, J. M a r e c k i, Leksykon godel..., s. 67.

${ }^{62}$ Podobnie jak wcześniej opisane godło tak i używane przez Kongregację Góry Koronnej widnieje na zakonnych pieczęciach, na winietach pism urzędowych oraz często jest stosowane jako emblemat zdobiący zakonne wydawnictwa.

${ }^{63}$ Por. Congregatio Eremitarum Camaldulensium Montis Coronae, http://www.araldicavaticana.com/zillustrazione04.htm (odczyt 1 XII 2005).

${ }^{64}$ Por. D. F or s t n er, Świat symboliki..., s. 84-86; W. Ko pa li ń s k i, Stownik symboli..., s. 101; J. E. C i r lot, Slownik symboli..., s. 141-143; J. T re sid de r, Symbole i ich znaczenie..., s. 116.

${ }^{65}$ Szerzej na temat biblijnego znaczenia góry zob. M. Lu rke r, Stownik obrazów..., s. $62-63$. 
Izraelitów był jak ogień pożerający na szczycie góry. Mojżesz wszedł w środek obłoku i wstapił na górę. I pozostał Mojżesz na górze przez czterdzieści dni i przez czterdzieści nocy (Wj 24, 12-18).

W tekstach Księgi Psalmów przewija się myśl pragnienia obcowania z Bogiem, który mieszka na górze Syjon:

«Przecież Ja ustanowilem sobie króla

na Syjonie, świętej górze mojej» (Ps 2,6).

Ześlij światłość swoją i wierność swoją:

niech one mnie wioda

i niech mnie przywiodą na Twoją świętą górę

i do Twych przybytków! (Ps 43,3).

Przekonanie o Jahwe mieszkającym na świętej górze podkreślają także inne księgi biblijne:

Widzenie Izajasza, syna Amosa, dotyczące Judy i Jerozolimy:

Stanie się na końcu czasów, że góra świątyni Pańskiej

stanie mocno na wierzchu gór

i wystrzeli ponad pagórki.

Wszystkie narody do niej popłyną,

mnogie ludy pójdą i rzekną:

"Chodźcie, wstapmy na Górę Pańską

do świątyni Boga Jakubowego!

Niech nas nauczy dróg swoich,

byśmy kroczyli Jego ścieżkami. Bo Prawo wyjdzie z Syjonu

i słowo Pańskie - z Jeruzalem» (Iz 2, 1-3).

Oczekuję Pana, który ukrywa swe oblicze

przed domem Jakuba, i w Nim pokładam nadzieję.

Oto ja i dzieci moje, które mi dał Pan,

stanowimy wieszcze znaki w Izraelu

od Pana Zastępów, co na górze Syjon przebywa (Iz 8, 17-18).

Pan Zastępów skierował następujące słowo:

«Tak mówi Pan Zastępów:

Zazdrosna miłość moja obejmuje Syjon

i broni go mój gniew potężny».

o mówi Pan:

«Powrócę znowu na Syjon

i zamieszkam znowu w Jeruzalem.

I znowu Jeruzalem nazwą Miastem Wiernym,

a górę Pana Zastępów - Górą Świętą» (Za 8, 1-3). 
$\mathrm{Na}$ kartach Starego Testamentu występują inne „święte” góry: Moria ${ }^{66}, \mathrm{Ne}$ bo $^{67}$, Karmel ${ }^{68}$, Garizim ${ }^{69}$. Z życiem Jezusa Chrystusa związane są liczne góry, $m$. in. Góra Kuszenia ${ }^{70}$, Góra Błogosławieństw ${ }^{71}$ oraz Góra Przemienienia (Tabor):

Po sześciu dniach Jezus wziął z sobą Piotra, Jakuba i brata jego Jana i zaprowadził ich na górę wysoka, osobno. Tam przemienił się wobec nich: twarz Jego zajaśniała jak słońce, odzienie zaś stało się białe jak światło. A oto im się ukazali Mojżesz i Eliasz, którzy rozmawiali z Nim. W tedy Piotr rzekł do Jezusa: «Panie, dobrze, że tu jesteśmy; jeśli chcesz, postawię tu trzy namioty: jeden dla Ciebie, jeden dla Mojżesza i jeden dla Eliasza». Gdy on jeszcze mówił, oto obłok świetlany osłonił ich, a z obłoku odezwał się głos: «To jest mój Syn umiłowany, w którym mam upodobanie, Jego słuchajcie!» Uczniowie, słysząc to, upadli na twarz i bardzo się zlękli. A Jezus zbliżył się do nich, dotknął ich i rzekł: «Wstańcie, nie lękajcie się!» Gdy podnieśli oczy, nikogo nie widzieli, tylko samego Jezusa (Mt 17, 1-8).

Z Męką Jezusa Chrystusa związana jest Góra Kalwaria (Golgota), chociaż ewangeliści nie wspominają że Jezus niósł krzyż na górę a tylko, że został ukrzyżowany na miejscu zwanym Golgotą lub Miejscem Czaszki ${ }^{72}$. Innym miejscem związanym z działalnością Jezusa Chrystusa jest Góra Oliwna, z której wstappił do nieba $^{73}$.

Góry są symbolem samotności i kontemplacji. Cnotę milczenia znacząco uwypukla Reguła św. Benedykta ${ }^{74}$. Współczesne zakonne Konstytucje kamedułów pouczają że

życie pustelnicze w naszym Zakonie jest całkowicie nastawione na zjednoczenie z Bogiem w ustawicznej modlitwie i kontemplacji (...). Samotność wiernie przeżywana jest nie tylko obrazem serdecznej zażyłości z Chrystusem, ale często ma także wymiar cierpienia $i$ walki. Kontemplacja jako niewyrażalne doświadczenie Boga znajduje szczególnie odpowiedni teren w naszej pustelniczej samotności. Istotnie, to właśnie w samotności i milczeniu Pan chętnie i bardziej intymnie objawia się pustelnikowi, który myślą i sercem wychyla się poza ten świat ku Ojcu, pozwalając mu w niewymowny sposób doświadczyć swojej obecności, swojej dobroci i swojej nieskończonej miłości $i^{75}$.

Góry są znakiem wyrzeczenia, umartwienia i pokuty. Życie kameduły jest nieustanną pokutą i wyrzeczeniem ${ }^{76}$.

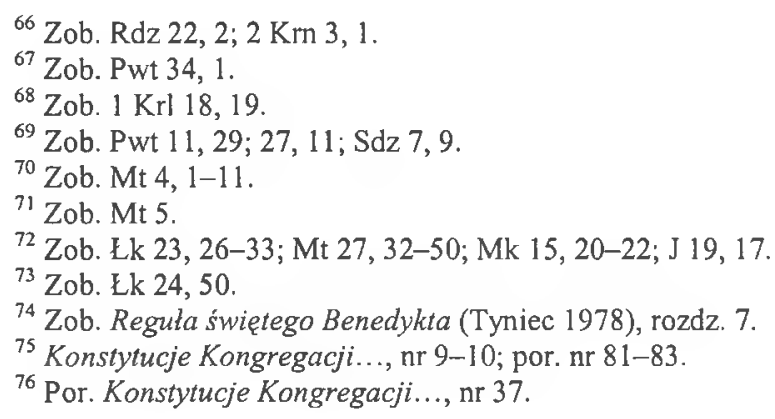




\section{$k r z y z$}

Znak krzyża występuje w wielu kulturach i nie należy wiązać go li tylko $z$ chrześcijaństwem. Krzyż ma wielorakie znaczenie ${ }^{77}$.

W chrześcijaństwie uważany jest za znak identyfikacyjny; występuje samodzielnie lub z pasją - wizerunkiem ukrzyżowanego na nim Jezusa. Pojawia się najprawdopodobniej w początkach IV wieku. Warto zaznaczyć, że początkowo nie przedstawiano na krzyżu Jezusa, najwyżej ograniczano się do ukazywania młodego mężczyzny trzymającego w rękach krzyż. Niekiedy obok krzyża lub na jego tle pojawia się baranek. Wizerunek umieszczonego na krzyżu Jezusa pojawia się prawdopodobnie w początku $\mathrm{V}$ wieku ${ }^{78}$. W 691 roku synod trullański postanowił, że w miejsce zamiast baranka na krzyżu należy umieszczać popiersie młodego mężczyzny; praktycznie umieszczano całą figurę Jezusa.

Współcześnie krzyż utożsamiany jest z Męką Chrystusa, wiara, że Jezus jako Syn Boży przez ofiarę krzyżową odkupił ludzkość z niewoli szatana oraz znakiem Bożej mocy. Krzyż więc oznacza zwycięstwo dobra nad złem, miłość i posłuszeństwo Bogu, ofiarę i samozaparcie. Symbolizuje także troski, kłopoty i udrękę, dobrowolne umartwienia i naśladowanie Jezusa ${ }^{79}$. Umiejętność dźwigania krzyża jest sprawdzianem bycia uczniem Jezusa:

Kto nie nosi swego krzyża, a idzie za Mną, ten nie może być moim uczniem (Ek 14, 27).

Kto nie bierze swego krzyża, a idzie za Mna, nie jest Mnie godzien. Kto chce znaleźć swe życie, straci je. a kto straci swe życie z mego powodu, znajdzie je (Mt 10, 38-39).

Współcześnie wyróżnia się około 400 rodzajów krzyży, które są powszechnymi motywami w heraldyce i symbolice. Krzyż trafił także do falerystyki. Znajduje się w centralnych miejscach w chrześcijańskich świątyniach i domach modlitwy.

Krzyż widoczny w godle kamedułów ma przypominać o dobrowolnym poświęceniu się Bogu, wyrzeczeniu się świata i dóbr materialnych oraz o ciaglym nawracaniu się ${ }^{80}$. Przypomina o pokucie i umartwieniu:

Życie eremu bezwzględnie wymaga ewangelicznego wyrzeczenia, co się wyraża $w$ umartwieniach wynikających $z$ naszego stylu życia. Byłoby złudzeniem, gdyby ktoś chciał pogodzić autentyczne życie zjednoczenia $\mathrm{z}$ Bogiem $\mathrm{z}$ szukaniem pewnych wygód, także tych powszechnie przyjętych w życiu świeckim. Jeśliby ktoś, pod natchnieniem Ducha Świętego, pragnąl podjąć większe

${ }^{77}$ Por. D. For st ne r, Świat symboliki..., s. 13-17; W. Ko p a li ń s k i, Stownik symboli..., s. 174-176; E. D a h l e r, Święta $i$ symbole..., s. 77-80; J. E. C i r l o t, Stownik symboli..., s. 208-209.

${ }^{78}$ Najstarsze z wyobrażeń zachowało się w Rzymie na drzwiach bazyliki dedykowanej św. Sabinie.

${ }^{79}$ Por. J. K u d a s i e w i c z, Logos i etos Krzyża, Warszawa 1980, passim; J. J a n i c k i, Krzyż, [w:] Stownik teologiczny, t. 1, Katowice 1985, s. 263-264.

${ }^{80}$ Por. Konstytucje Kongregacji..., nr 16-26. 
ostrości reguły wspólnej, niech to czyni z błogosławieństwem Przeora, który nie odmówi go zwłaszcza temu, który umartwia się podporządkowując się nade wszystko posłuszeństwu, jednak bez wzbudzania podziwu u innych i bez zakłócania spokoju posługującym. Św. Piotr Damiani uczy nas: «aby nasza samotność i nasza pokuta były owocne, powinny być zawsze przyprawione solą posłuszeństwa, które nas zbawia» (Św. Piotr Damiani, Opusc. 15. 18) ${ }^{81}$.

\section{korona}

Korona powszechnie kojarzy się z symbolami władzy. Noszona na głowie jest atrybutem króla lub księcia, leżąca u stóp jest znakiem pogardy dla dóbr ziemskich; może także oznaczać utracone królestwo ${ }^{82}$.

Korona może mieć wieloraki kształt i być wykonana na różne sposoby. W starożytności znane były korony sporządzane z liści laurowych (wawrzynowych) lub złote imitujące wawrzyn. Złoty wieniec laurowy nosił cesarz jako zwierzchnik wszystkich legionów. Heraldyka zna m. in. korony królewskie, książęce, margrabiowskie, hrabiowskie, baronowskie, szlacheckie, miejskie i gminne ${ }^{83}$.

W symbolice religijnej szczególne znaczenie ma korona ciemiowa. Najczęściej przedstawiana jako wieniec uwity z kolczastych krzewów lub też jako przedstawiana jako kołpak wciśnięty na głowę Jezusa przez żołnierzy rzymskich podczas przetrzymywania go w pretorium. Korona cierniowa (lac. corona spinea) symbolizuje ból i cierpienie, znęcanie się nad niewinnym człowiekiem, trudną sytuację życiową. Jest także parodią wieńca $\mathrm{z}$ róź ${ }^{84}$.

Godło Kongregacji Pustelników Kamedułów Góry Koronnej przypomina o stałej dążności do doskonałości i upodobnienia się do Jezusa Chrystusa w duchu wskazań bł. Pawła - organizatora pierwszych eremów tejże Kongregacji. Samotność winna sprzyjać zjednoczeniu z Bogiem, ciagłej kontemplacji i modlitwie. Tak rozumiana samotność domaga się odwagi i stałości niezbędnej do dążenia do doskonałości. Życie eremity jest ciagłym naśladowaniem Jezusa Chrystusa aż do zaparcia się siebie a wszystkie akty pokutne podejmuje z miłości do Boga. Kamedułę, jak każdego duchowego syna św. Benedykta, powinna cechować szczególna cecha umartwienia $^{85}$. Celem ostatecznym kameduły jest ofiarowanie swego życia za zbawienie innych, życie wieczne i zjednoczenie się z Chrystusem. Jezus jest koroną wieńczącą wszelkie ziemskie dążenia, pragnienia i działania eremity ${ }^{86}$.

\footnotetext{
${ }^{81}$ Konstytucje Kongregacji..., nr 37.

${ }^{82}$ Por. J. E. C i r lot, Stownik symboli..., s. 197.

${ }^{83}$ Por. G. O s wal d, Lexikon der Heraldik..., s. 234-239; S. G ó r z y ń s k i, J. Koc h a now s k i, Herby szlachty polskiej, Warszawa 1990, s. 24-26; P. D u dz in s k i, Alfabet heraldyczny, Warszawa 1997, s. 20-24; J. T r e s i d d e r, Symbole i ich znaczenie..., s. 138.

${ }_{84}$ Por. W. Ko palińs k i, Stownik symboli..., s. 162; J. Tr e sidder, Symbole $i$ ich

${ }^{85}$ Por. Regula świętego Benedykta..., rozdz. 39-41.

${ }^{86}$ Szerzej na ten temat zob. Regula św. Benedykta $i$ Konstytucye..., passim.
} znaczenie..., s. 138. 
Analizując zakonne godła poszczególnych wspólnot zakonnych rozpoznajemy ich cel działania oraz duchowość. Te ogólne założenia odnoszą się także do prezentowanych wyżej dwóch godeł używanych przez kamedułów. By zrozumieć wymowę znaków używanych przez zakonną wspólnotę należy także sięgnąc do jej początków, do założycieli i dziejów na przestrzeni wieków. Dzięki badaniom heraldycznym opartym na przesłankach historycznych i prawodawstwie zakonnym możemy prześledzić kształtowanie się charyzmatu i jego ewolucję. Dzięki temu poznajemy wartość i znaczenie życia zakonnego a tym samym bogactwo Kościoła.

\section{Summary}

Through an analysis of coats of arms of various monastic communities we recognize their goals and spirituality. These generalizations apply as well to the two coats of arms presented in this paper, which have been used by the Camaldolese Order. In order to understand a message of signs used by a congregation one should refer to its beginnings, founders and history over the centuries. Heraldic research based on historical context and monastic legislature enables us to follow the forming of charisma and its evolution. It enables us also to learn about the value and importance of monastic life and hence, the richness of the Church. 

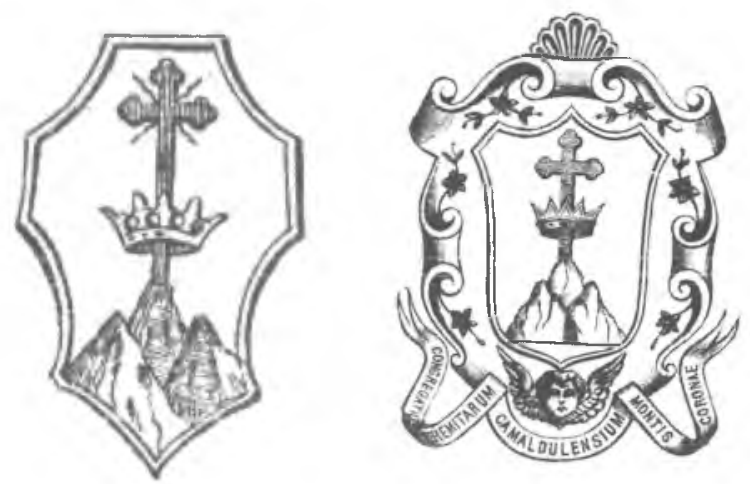

Godła Kongregacji Pustelników Kamedułów Góry Koronnej

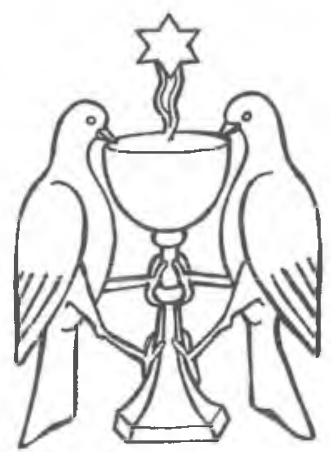

Godło zakonu kamedułów

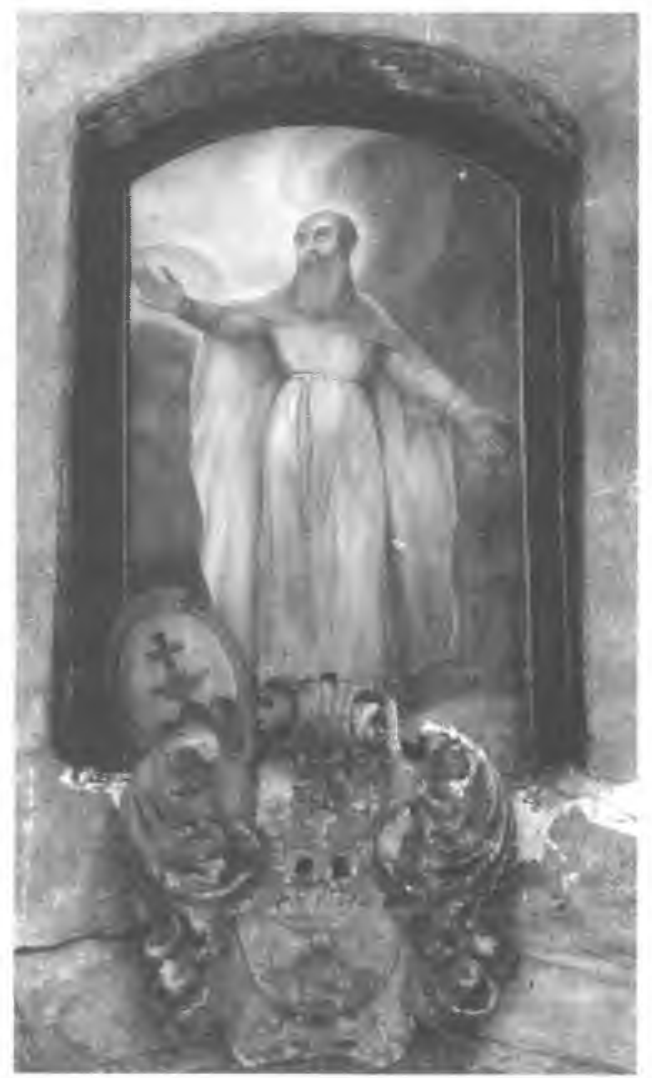

Kartusz z godłem kongregacji Monte Corona. Czerwony Klasztor 